\title{
Recreational use and health functions of allotments gardens in the Katowice conurbation, Poland
}

\author{
Edward Duś
}

Department of Economic Geography, Faculty of Earth Sciences, University of Silesia, Będzińska Str. 60, 41-200 Sosnowiec, Poland E-mail address: edward.dus@us.edu.pl

\begin{abstract}
Allotment gardens are multifunctional elements of urban space, which have been shaped by various strands of development, among which a significant role is played by health purposes and recreational use. Different aspects and problems of the recreational use of allotments in the industrial area of the Katowice conurbation in Silesia, southern Poland are the scope for this analysis, and are considered against the background of their historical development. Allotment gardens are important components of an urban recreation system, and a primary base for recreation by the owners of these allotments. Time spent in gardens is filled with physical activities associated with taking care of them and also for passive recreation. An advantage is the possibility to spend leisure time, especially by hard working people or those with limited possibilities to access other forms of recreation. An advantage is the possibility to spend leisure time, especially by hard working people or those with limited possibilities to access other forms of recreation. The date of commencement of work and the number of people spending leisure time on the plots are dependent on weather conditions and being at the disposal of free time. Therefore, recreation is characterized by seasonality, and reveals significant differences in the number of allotment users each day. Socio-economic changes in the last few years have resulted in significant changes in the methods of utilising these gardens and the type of recreational use of individual allotments.
\end{abstract}

KEY WORDS: allotments, city, forms of recreation, active leisure time, use of allotment gardens

\section{Introduction}

Cultivated greenery, especially parks and allotment gardens serve a fundamental role in the area of local resting. Each green area integrated into urban space carries out certain social objectives, with limited possibilities for their mutual substitution (ToŁWIŃSKI, 1963; PIĄTKOWSKA, 1972; GRAHN, 1985; BELlOWS, 2004; CHIUSURA, 2004; MAJDECKI, 2008; PAWLiKoWSKA-PiechotKA, 2009). The widespread availability of parks in cities ensures their intensive use for recreational purposes, while allotment gardens allow for a greater intimacy and diversity of recreational forms. Allotment gardens are an important component of the recreational system (TCHÓRZ, 1977; CROUCH \& WARD, 2007), as they have a significant share of $31.8 \%$ in the structure of urban green areas.
The aim of this paper is to present various forms of recreational use of allotment gardens in the Katowice conurbation and their changes over time resulting from changes in social and economic situations. Some aspects of development and the level of use of garden space for recreation are also subjects for discussion. To a lesser extent, attention was drawn to widely understood ecological and socio-educational functions performed for the local community. The empirical material collected during field work for this study constitutes the basis for this analysis, including observations and an inventory of a selected group of allotment gardens, as well as interviews with users.

The study area includes 16 cities in the core zone of the Katowice conurbation populated by 2,009,600 people (KrZYSZTofiK, 2008; Duś, 2013). In 2012, there were 386 allotment gardens here, constituting 612 garden colonies, which occupied 2737.34 hectares. The allotment gardens are used 
by 686,000 households, representing $8.3 \%$ of their total number in the Katowice conurbation, which comprise $6.4 \%$ of the gardens, and $7.2 \%$ of the allotment garden users in Poland (POLISH AsSOCIATION OF ALLOTMENT USERS, 2012).

\section{The role of allotment gardens in urban space}

Allotment gardens are multifunctional elements of urban space, which have been shaped by various strands of development. The pace of their formation has depended on their location and particular time of development. In the conditions of various organizational and legal restrictions, they have been formed mainly under the influence of unfavourable socio-economic situations with a consequent focus on food production. In the Katowice conurbation, five functions of gardens have co-existed, namely: food provision and economic, recreational-health, ecological, landscape and socio-educational. The scope of their functions and changes over time are reflected in the way gardens have developed and the individual usages of allotments (DUŚ, 1990, 1992, 1993, 1997).

The contemporary state of allotment gardening has been formed by two trends of development, which were the main reasons for the establishment of gardens. The food provision and economic functions have been of greatest importance, which makes the economic aspects of garden use a popular subject of discussion in the literature (ARNOLD, 1960; RILEY, 1979; MORAN, 1990; PEREZ-WAZQUez ET AL., 2005; ACTON, 2010). This type of activity intensified in the second half of the nineteenth century, at the time of capitalist industrialization, and reached its peak in intensely developed industrial cities in England, France and Germany. The second trend was related to promoting new concepts in the field of urban development planning in the Modernism period, which were formulated in the context of fairly widespread public protests against deteriorating conditions of hygiene and health. Recreational and health-improving gardens, established in industrial cities, and were an attempt to adapt the organization and functions of urban space and greenery to the new social needs in the conditions of the emerging capitalist socio-economic structures (TOŁWIŃSKI, 1963; MAJDECKI, 2008).

\section{Development of the recreational function}

It is generally assumed in the literature that the originator and main proponent of allotment gardening was a physician, Daniel Gottlieb Schreber (1808-1861), whose patients were primarily children from poor families from industrial districts of Leipzig. He used a slogan: "get out of stifling apartments to the sun and air", whose practical implementation was hampered by the lack of free land in housing estates deprived of green areas. The significant demand for new land from the growing industry and construction and the operation of speculative investors and land owners did not allow for the creation of suitable green areas. A partial solution to the problem was proposed by his friend - Ernst Innocent Hauschild, who started flower beds, cultivated by students in the free space within the property of the school that he managed and next to them a children's playground designated for shared use was established. A parents' interest in working in the garden triggered the need to establish gardens for adults (DZIAŁKOWIEC ŚLĄSKI, 1935; DZIAŁKOWIEC, 1970).

Gardens for adults consisted of colonies of several dozen plots of $100-150 \mathrm{~m}^{2}$ each and a playground for children with appropriate facilities, an administration and social building (grocery store, coffee shop, utility room), sports facilities (football field, tennis courts, swimming pool), and other recreational facilities. Arranging such gardens required substantial finances, therefore the users of the allotments were mostly of affluent families who started associations on cooperative principles. The movement initiated by Schreber included the principle to raise the level of public health. The initiative of the Red Cross emerged from this trend in the form of organizing gardens for recuperating tuberculosis patients and families with contact with tuberculosis (FAMILIENGARTEN..., 1913).

Health-improvement and recreational functions were the inspiration for the establishment of many gardens initiated by doctors and educators. The keynote was to ensure proper physical development of children and youth through gymnastics and games organized in the open air gardens. The oldest garden in Poland "Sun Baths", founded in 1897, in Grudziądz under the initiative of Jalkowski, M.D., housed a society promoting a natural way of life, which was very controversial at the time, and divided the city inhabitants into supporters and fierce opponents, who considered these activities immoral. According to the preserved description "(...) members of society, half-naked practised gymnastics, training, rested in deckchairs or took baths in specially prepared baths filled with turf mud, heated by sun rays" (PRZEKRóJ, 1983). A similar idea reached Upper Silesia where, in 1905, the first garden was founded in Huta Królewska (presently Chorzów), where a special 
area was designated for sun and air baths, a garden concert hall was established, a bowling alley was built and fields were designed for adequate facilities; also equipment for recreation was purchased (DZIAŁKOWIEC ŚLĄSKI, 1935-1936).

Significant changes took place during World War I when, in order to improve food supplies, earmarking land for the cultivation of vegetables was initiated. In the existing gardens areas designated for common recreational purposes were liquidated or significantly limited. An average allotment garden size increased to $300 \mathrm{~m}^{2}$. There was also a very rapid increase in the number of allotments established not in an organized way that served the poorest population as a source of food supply, but also addressed their need for contact with nature. Such gardens were characterized by a short period of use and generally their location on the outskirts of workers' settlements was temporary.

Similar development trends prevailed in the inter-war period, when most gardens were established in areas of industrial societies that were interested in allocating land for the cultivation of vegetables and potatoes. An important obstacle in the proper development of allotment gardening was the lack of laws regulating the legal status of gardens, which raised problems relating to the location and methods of management. In Poland, development conditions have not changed significantly until modern times, though gradual changes have taken place in the arrangement of gardens and individually used allotments (Duś, 2013).

Currently, allotment gardens are very characteristic elements of the urban and industrial landscape of the Katowice conurbation (Tab. 1). They occupy $2.2 \%$ of the area of these discussed cities, although their participation varies from 0.5\% in Dąbrowa Górnicza to 5.9\% in Chorzów. With an average area of $13.3 \mathrm{~m}^{2}$ of gardens per 1 inhabitant in urban conurbations, the highest values have been recorded in Czeladź - $21.6 \mathrm{~m}^{2}$, Gliwice - $18.8 \mathrm{~m}^{2}$ and Chorzów, and the lowest under $7 \mathrm{~m}^{2}$ per person in Dąbrowa Górnicza and Katowice.

In the process of development and evolution of the idea of allotment gardening, the importance of the leisure function has increased steadily with the simultaneous change of its forms. The leisure function has been preserved in social consciousness, which is expressed in the names of the gardens 40 out of 460 gardens in the Katowice conurbation have a name connected with leisure, such as: Leisure - 8, Relaxation - 8 and Seclusion - 7 gardens.

Table 1. Allotment gardens in the Katowice conurbation in 2012 (after Registration Cards for Employee Allotment Gardens in the Silesian District Board of the Polish Association of Allotments in Katowice)

\begin{tabular}{|c|c|c|c|c|c|c|c|}
\hline \multirow{2}{*}{ No. } & \multirow{2}{*}{ Cities } & \multirow{2}{*}{$\begin{array}{l}\text { Population in } \\
\text { thousands }\end{array}$} & \multicolumn{2}{|c|}{ Number of } & \multirow{2}{*}{$\begin{array}{c}\text { Area of } \\
\text { gardens in ha }\end{array}$} & \multirow{2}{*}{$\begin{array}{l}\text { Percentage } \\
\text { share of urban } \\
\text { greenery }\end{array}$} & \multirow{2}{*}{$\begin{array}{c}\text { Number of } \\
\text { allotment } \\
\text { gardens }\end{array}$} \\
\hline & & & gardens & colonies & & & \\
\hline 1. & Będzin & 58.7 & 6 & 10 & 74.78 & 27.1 & 2271 \\
\hline 2. & Bytom & 174.7 & 32 & 63 & 269.44 & 44.8 & 6868 \\
\hline 3. & Chorzów & 111.2 & 29 & 36 & 207.84 & 21.9 & 5023 \\
\hline 4. & Czeladź & 33.3 & 4 & 27 & 75.57 & 34.9 & 1907 \\
\hline 5. & Dąbrowa Górnicza & 124.7 & 15 & 19 & 95.78 & 17.5 & 2900 \\
\hline 6. & Gliwice & 186.2 & 65 & 93 & 371.88 & 43.1 & 8923 \\
\hline 7. & Jaworzno & 94.3 & 10 & 15 & 82.03 & 23.2 & 2153 \\
\hline 8. & Katowice & 307.2 & 49 & 78 & 210.53 & 17.0 & 5491 \\
\hline 9. & Mysłowice & 75.3 & 12 & 16 & 61.19 & 39.6 & 1763 \\
\hline 10. & Piekary Śląskie & 57.5 & 10 & 11 & 95.95 & 50.6 & 2306 \\
\hline 11. & Ruda Śląska & 142.3 & 26 & 45 & 167.47 & 30.5 & 3993 \\
\hline 12. & Siemianowice Śląskie & 69.5 & 20 & 27 & 114.41 & 32.8 & 2795 \\
\hline 13. & Sosnowiec & 213.5 & 30 & 62 & 367.98 & 40.9 & 8789 \\
\hline 14. & Świętochłowice & 52.4 & 10 & 13 & 53.48 & 22.5 & 1476 \\
\hline 15. & Tychy & 129.1 & 37 & 38 & 140.77 & 25.5 & 4284 \\
\hline \multirow[t]{2}{*}{16.} & Zabrze & 179.5 & 31 & 59 & 348.24 & 56.5 & 7645 \\
\hline & Total & 2009.6 & 386 & 612 & 2737.34 & 31.8 & 68587 \\
\hline
\end{tabular}




\section{Their importance for social health}

Recreation is any activity undertaken to regenerate energy in order to achieve good health, which is the equilibrium of physical, mental and social state. To ensure this balance, one should rationally use various forms of recreation, especially appreciating the importance of physical recreation as the best form of relaxation (ROMANOWSKI \& EBERHARDT, 1972). The issue of recreation is quite often discussed in literature, although information about its size and scope are usually too general (IZDEBSKA, 1979; KOŁOMYJSKA, 1982; MAIER, 1988; PAWLIKOWSKAPIECHOTKA, 2009).

A wide range of the concept of recreation enables its application to all activities carried out in allotment gardens by their users and members of their families. The length of stay in the garden is filled with activities related to active leisure, as well as passive leisure, preferred by younger people, including: reading, resting and socializing. Although the duty of gardening dictated by the natural rhythm of nature makes staying in the garden is a half of free time, but these indispensable actions are favourable for the regeneration of physical and mental health. All working people have an opportunity to perform actions adverse to their professional duties and they are most appropriate for people who excessively and unilaterally exploit their mental and physical strength at work (BUTRYMOWICZ, 1971; IZDEBSKA, 1979; ARMSTRONG, 2000; BROWN \& JAMETON, 2000; WAKEFIELD ET AL., 2007).

The location of gardens relatively close to places of residence, makes this form of recreation facilitate daily movement due to walking there and back home. Plant maintenance work is associated with greater or lesser physical effort, which does not pose a limitation for any age group. Another advantage is the opportunity to rest there for the majority of the year.

In addition to the general factors determining the process of physical and mental recreation, the use of allotment gardens is important for retired people (AUSTIN ET AL., 2006; VAN DEN BERG ET AL., 2010). Gardening reduces the traumatic impact of rapid transition to retirement and is conducive to alleviating the feeling of uselessness. Apart from material benefits, it provides many aesthetic and emotional experiences and allows for a wider access to people with similar interests. Thus, in this period of life, many people decide to take on an allotment garden (BUTRYMOWICZ, 1971; KAMIŃSKI, 1971; KоєOMYJSKA, 1982). Such an activity is a particularly attractive, as it is fully approved by the family and social circle. Work in the garden creates a lot of opportunities to trigger initiative and creativity and to maintain a high degree of mental and physical activity. The effects of working to shape a nicely cared for garden are reasons for satisfaction; allotments moreover allow for other recreational activities including cultural, artistic, and especially technical activities, which are frequently impossible in small apartments.

An allotment garden combines the elements of nature and the culture of gardening, which give it a suitable form. The method of working applied by garden users, depends on the stage of garden development, ensures the implementation of individual or social interests, which are a source of personal satisfaction. According to the needs and methods of usage, one of the intertwining elements of nature and culture is more important, and it creates varied spatial layouts encountered in the gardens, in depends on the individual characteristics of the user. Variety, contrast and absorbency of allotment gardens make urban space more attractive from the point of view of recreation (SAARINEN \& SELL, 1981; HALL \& PAGE, 1999; CROUCH \& WARD, 2007).

The recreational value of the environment of allotment gardens is set by an intimate spatial scale, covering a distance of 20 meters from the observer. Micro-space architecture, including: shapes, contrasts of colour, size and colour of these arrangement elements (trees, shrubs, flowers) is essential in sensory perception. Thus, allotment gardens fulfil a significant role in the field of mental recreation, and its most important element is the perception of certain colours and shapes. Health-impact factors during relaxation in allotment gardens are properly modified physical, chemical and biological stimuli (TOYNE, 1978; ORZESZEK-GAJEWSKA, 1982; LENIHAN \& FLETCHER, 1996; VAN DEN BERG ET AL., 2010). The use of gardens allows one to create a composition of individual character in terms of colours and shapes. Warm colours enhance the sensation of the sound level, while the greens dampen sounds and are calming. Cyclical changes in the greenery and colours that are associated with life and passing are influential. Shapes affect the human psyche in a more complex way. Therefore, a variety of tastes of allotment users make the process of design and development happen from the perspective of the interior of the allotments, which may be in conflict with the need of the composition of the garden as a whole that is in harmony with the environment. 


\section{Group forms of recreation}

The rapidly increasing number of allotments during World War I and after allowed for the benefits of working outdoors to be felt by the poor and those workers with the worst hygienic conditions - miners and smelter workers. For children from poor families affected by unemployment, day camps were organized. Collective forms of recreation were firstly organized in 1934, with 300 children attending 2 and 4-week holidays in Chorzów. In 1938, in what was then the Silesian voivodeship, the number of children participating in these types of classes increased to 5,000 and 8,000 in Poland. The children stayed in gardens under the care of counsellors, benefited from recreation facilities and participated in organized tours. A limitation to the wider development of the program was the lack of recreational buildings adapted for such activities, since only a few allotment gardens had a common room and equipment necessary to meet the required recreational function (DZIAŁKOWIEC ŚLĄSKI, 1934-1939).

Since the beginning of the 1960s, some gardens organized collective forms of stay for several hours in the summer, which was attended by 2-3,000 children annually. This form of recreation became less and less popular, and was abandoned in 1980, which was probably due to increased access to public playgrounds for children and organized camps for employers. The importance of arranged recreation grounds, previously present in half of allotment gardens, significantly decreased. They were most frequently equipped with devices such as swings - $46 \%$, sandpits - $35 \%$, merry-gorounds - $26 \%$, see-saws - $16 \%$, swimming or paddling pools - $7 \%$ and slides - $5 \%$.

In the past, holidays for the elderly organized by about 70 allotment boards and field offices of the Polish Committee for Social Welfare and the Association of Pensioners and Disabled was of some importance. The number of participants increased to more than 5,000 a year in the early 1980 s, but with time they have become less and less popular. It should be emphasized that this form of holiday was popular among the elderly, mostly lonely people with low living standards, who did not benefit from package holidays. This voluntary work had a deeply humane meaning. Allotment gardens housed a common room with social and living facilities for recreation. About 30 gardens had a set of social games or equipment for sports for adults. In the most popular period, in the Katowice conurbation, a holiday package was used by $20 \%$ of all people taking part in this form of leisure in Poland.

As early as the period before World War II recreational programs were launched by opening some allotments for the use of the population. A combination of the existing functions of gardens with an extended program of generally available greenery did not bring positive results and further implementation was discontinued (PiątKowSKa, 1972). A more common usage for recreational purposes occurs only in areas where walking paths are next to gardens (PAWLIKOWSKAPIECHOTKA, 2009). Allotment gardens can be classified as subjective spaces of tourism exploration, described by LISZEWSKI (2009).

\section{Results of empirical research}

Allotment gardens are quite strictly associated with individual structural units of a city, that is the residential districts of multi-family developments. Such an arrangement of gardens allows for a situation that, for the majority of garden users, the distance between the garden and their house is less than $1 \mathrm{~km}$, which coincides with the range set by a 15-minute walking isochrone (PIĄTKOWSKA, 1972; SZKUP, 2013; Duś, 2013).

Based on field observations conducted in 12 allotments located in Bytom, Gliwice, Sosnowiec, Ruda Śląska and Zabrze, the number of people residing in the selected area was calculated. The study was conducted in the period from March to October at different times of day and in different weather conditions. The results and information obtained from interviews formed the basis for estimating an average number of people using the allotment on a daily.

\subsection{Motives for using allotments}

Social interest in owning allotment plots is the result of atavistic needs that motivate people to act. Research conducted by the author for more than 30 years indicates that the preference to own an allotment has changed over time; a clear decline in interest in an allotment as a source of economic benefits has been observed countered by a clear increase in the importance of their recreational value. According to the research of 1982 conducted during a food crisis, $73 \%$ of applicantions for allotment gardens indicated the need to procure food. In the most recent research, allotment users chose the motives for owning a garden, and ranked the motives listed in the survey. Respondents most frequently mentioned leisure reasons $-24.3 \%$ of respondents including 
$39.7 \%$ who ranked this motive first. In addition, $16.9 \%$ indicated that it was a way of spending free time (12.9\% ranked in first position). A further $18.0 \%$ drew attention to health reasons $(8.1 \%$ ranked in first position), and $18.3 \%$ (28.7\% ranked as first) mentioned a passion for working in the garden. An analysis of research in the literature indicates that the motives are characterized by diversity due to the variability of the places and the timing of the research and the ways in which the problem was formulated by various authors (WEJCHERT, 1969; BUTRYMOWICZ, 1971; MATCZAK \& SZKUP, 2010). In the most recent study, SzKUP (2013) has shown that for $63.8 \%$ of users of family allotment gardens in Łódź, the main motive for owning a garden was the need to have a rest. In all the studies, garden owners identify the following significant motives for the use of gardens as: relaxation and healthimprovement reasons, a passion for working in the garden and, less frequently, economic benefits.

\subsection{Family leisure use of allotments}

The period from spring to autumn is the main usage time, and mostly men, have their leisure, of whom $52 \%$ visit their garden, generally every day, a further $31 \%$ visit between 4-6 days a week, and only every fifth user comes less regularly. Most people usually spend over 20 hours a week, and 35\% even more than 40 hours at their allotment. This applies largely to pensioners, for whom the garden becomes the principal place of leisure in summer and also places where they occasionally live. In winter, $44 \%$ of users do not visit the allotments at all, and others come only occasionally.

The allotments are used for leisure more or less regularly by a total of $56 \%$ of family members of the allotment owners, a further $28 \%$ stay relatively rarely and briefly, and only $14 \%$ of the population does not benefit from this form of recreation at all. Family members enjoy resting on allotments mostly on non-working days. A group of $35 \%$ of family members, mostly retired people and health pensioners, stay on the site an average of more than 10 hours a week in the summer. Spouses, sometimes with grandchildren, usually spend a large part of the day there, especially when their garden sheds have equipment to prepare meals. On the basis of the family size of the allotment owners and the time spent on the allotments, it can be assumed that nearly 140,000 people spend their leisure in their allotment gardens more or less regularly, representing 7.0\% of the population of the Katowice conurbation.
In this group, 95,000 people, i.e. $4.7 \%$ of the population spend their free time in such a way on a regular basis. In addition, by invitation from the owners, groups of their friends occasionally spend time in the allotments as well.

An important role in raising the recreational value is investment in the gardens and the technical equipment of individual plots. The older gardens are characterized by a significantly lower availability of equipment and various systems. An extended stay and a comfortable rest is provided by a suitably equipped garden sheds. In the research, $96 \%$ of the gardens had different forms of cabins, whose size varied from 3 to $38 \mathrm{~m}^{2}$, with an average of $15.5 \mathrm{~m}^{2}$. Nearly one-third of them are in good condition, fairly extensive and well made, and the better equipped ones are like cottages. Cabins with of one room serving both residential and utility functions, representative of $47 \%$ of the total, those with two - $37 \%$ and $16 \%$ of cabins have more rooms. In recent years, the number of dilapidated cabins has increased and they now represent almost $20 \%$ of their total number.

Equipment in garden sheds generally includes: a bed $-73 \%$, electricity - $58 \%$, and water - $24 \%$, although it is brought up to $92 \%$ of the plots. The most important facility is the availability of electricity, which helps to solve a number of social and living problems during a longer stay. A relatively small number of allotments - 1-2\% have amenities such as a bathroom, heating, a TV, a radio, and other items, necessary for a comfortable stay. Purchasing better equipment for cabins is quite often discouraged due to theft and vandalism of equipment. Monitoring and specialized protection may prevent crime, which, however, in the case of the conurbation is happen quite rarely. Some of the equipment is brought on each occasion for the duration of the stay.

\subsection{Seasonal and daily schedule of leisure time}

Leisure in allotment gardens is characterized by a large variability in individual months of the year (Tab. 2). In the period from November to February, users only occasionally stay there and in March and in October large fluctuations are reported due to weather conditions. Most people have their leisure in May - an average of 37 people, and during non-working days 46 people per 1 ha of gardens. A large turnout in May and June is connected with the necessity to perform basic horticultural and maintenance work in the garden, due to rapid vegetative growth of plants, 
aesthetic experiences caused by flowers and flowering fruit trees and emitted scents. In addition, during this period there are no other leisure options, as leisure centres and swimming pools are still closed. A significantly smaller number of users come in July and August due to their increased participation in other forms of recreation, associated with longer holiday trips and summer camps. However, about $15 \%$ of allotment owners of the working population spend their holiday leave in this way.

Table 2. Average daily number of people spending the leisure time in allotment gardens in the cities of the Katowice conurbation

\begin{tabular}{|l|c|c|c|}
\hline \multirow{2}{*}{ Months } & \multicolumn{2}{|c|}{ Number of people } & \multirow{2}{*}{ Average value $=100$} \\
\cline { 2 - 3 } & In thousands & People per 1 ha & \\
\hline March & 9.1 & 4 & 19.7 \\
April & 57.2 & 25 & 123.5 \\
May & 84.6 & 37 & 182.7 \\
June & 75.4 & 33 & 162.9 \\
July & 54.9 & 24 & 118.6 \\
August & 43.4 & 19 & 93.7 \\
September & 32.0 & 14 & 69.1 \\
October & 13.7 & 5 & 29.6 \\
\hline Average & 46.3 & 20 & 100 \\
\hline
\end{tabular}

Leisure time spent at the allotments is characterized by an uneven distribution during the day and an increase by about $30 \%$ in the number of people staying there on non-working days. In the period from March to October an average number of people who stay in the allotment gardens during the day is 20 for the area of 1 ha, including 18 on weekdays and 26 on days-off. In total, during the research period, an average of 463,000 people visited their allotment daily, representing $2.3 \%$ of the Katowice conurbation population.

The number of people having their leisure time during the day varies from 4 people between 10:00-11:00 am to 6-7 people at lunchtime and rises to a maximum of $15-16$ people per 1 hectare between 5:00-7:00 pm, and then rapidly decreases after that. The attendance also depends on the social composition of the users, which is presented broadly by SzKUP (2013). Some gardens have a strong relationship with the nearby housing estates, while with others, usually older gardens, this relationship is clearly looser, as a result of multiple changes of user. An important factor that modifies the overall regularity is the location of these gardens, in respect to the place of residence of the user.

The gardens located closest to housing estates places of residence of users have the biggest impact on the turnout, because they allow for the stay of residents who do not own gardens. Usually a shorter stay in these gardens has a high frequency. In the highest period of use 15:00-7:00 p.m.), the number exceeds the usual 25 people per 1 ha of garden, with more people taking a rest there on weekdays than on holidays. Gardens located at a slightly greater distance (1-1.5 km), are characterized by a higher proportion of pensioners in the make-up of the users and hence the relaxation is characterised by a longer stay, although the number of people per 1 hectare of garden is usually the lowest in the entire community of gardens. In the highest attendance period, it does not exceed 15 persons per 1 ha of garden, and there are usually smaller differences in the daily distribution of the number of persons between the morning period and the afternoon period. This applies especially to older gardens where a multiple change of users has already taken place.

Allotment gardens located away from residential areas are usually characterized by a shorter usage time and a higher participation of the working population in the structure. They also have a high degree of investment and technical equipment, which allows for a longer stay. In the afternoon there is the highest number of people resting there, usually more than 20 and with favourable weather conditions in non-working days, the number reaches 50-60 people per 1 ha.

\section{Discussion}

In the evolutionary process, the development of allotment gardens is characterized by a strong tendency to reduce food growing, especially vegetables. In 1980, the area designated for crops covered an average of $34 \%$ of each plot and was 
mostly used to grow vegetables - 25\%, strawberries - 3\%, and flowers - 6\%. In recent years, this area has declined to an average of $16 \%$, including vegetables accounting for only $6 \%$, strawberries $3 \%$ and $7 \%$ for flowers. In the beginning of the economy transformations, in conditions of improvement of the food supply, over $40 \%$ of allotment owners have virtually given up growing vegetables (Duś, 1993, 1997). The existing trend in the use of gardens is highly desirable due to the contamination of soil and plants with compounds harmful to human health (KUCHARSKI, 1988; BROWN \& JAMETON, 2000). Currently, cultivation is usually limited to a small area of vegetable patches. It should be emphasized that the methods of garden use result from individual user preferences and display a great diversity of content both between gardens as well as in individual gardens.

The number of planted trees, shrubs and flowers has systematically been increasing and the most characteristic element of development is a more or less carefully maintained lawn with decorative plants. Around 1980, only every fifth gardener planted ornamental trees, whereas now there is an average of 2 exotic trees per allotment. The number of ornamental shrubs has significantly increased in addition to the formerly very popular cultivation of roses. In the past, a visible manifestation of recreational use of the land was a tendency to build more and more comfortable garden sheds, but this process was halted in the market transformation period.

An insufficient amount of vacant land in the cities meant that in the 1970s the concept of suburban allotments emerged, with better facilities for recreation and sports equipment and accessories that allow for a weekend stay. Their distance from places of residence in Poland ranged from a few to $80 \mathrm{~km}$, but their substitute role in relation to urban gardens was provided only due to the location of the gardens with public transport access. A significant obstacle to wider popularity was the high costs of furnishing at that time. In addition, a small degree of substitution of public gardens and suburban gardens (camping gardens) resulted from their different characteristics and preferences of potential users. Although the establishment of such gardens was started, it was their practical implementation that did not have a great importance due to the simultaneous development of suburban weekend recreation centres. Within a few to a dozen kilometres, in the area of the Protective Forest Belt of the Upper Silesian Industrial Region, numerous recreation centres were developed for weekend rest (KRAUZE, 1979). Both of these forms of daily recreation within the city and the suburban one (weekend) complement each other, since they are used by different groups of people. Centres in the suburban area are used for collective recreation and devoid of a more intimate form, characteristic of allotment gardens.

In the period of market transformations in the economy after 1990, some qualitative changes took place in the use of allotment gardens and in leisure time spent there. Favourable legislation regarding the acquisition of land promoted them as well as an improvement in the supply of building materials, and other social and economic factors. During this period, social demand for allotments lessened, which resulted from the large growth of their area in the 1980s. Their importance for the working population has decreased and now they mostly serve people who are less active professionally.

The growing affluence and increased spatial mobility, resulting from the very dynamic development of individual transport in conjunction with changes in patterns and preferences for leisure activities meant that there has been some re-evaluation of the function of recreation. As a result of these changes, numerous colonies of "week-end homes" have emerged, mainly in the Krakow-Czestochowa Upland and in the Beskids. These facilities form characteristic concentrations similar to allotments. Residents build houses for leisure use outside the city, in tranquillity and proximity to nature, and it is also a means of capital investment and a symbol of social status (ANDRIOTIS, 2006). "Second homes" are constructed in the most attractive areas in the mountains, hills, within river valleys, and in areas not useful for agriculture (СоРРоск, 1977). A significant role in shaping the attitudes of perception and motivation in the choice of means of recreation is given to a group of diverse social conditions (BERRY, 1980). An important role in choosing the location of an allotment garden is played by the qualities of the surrounding natural environment (KoWALCZYK, 1993; MiKA, 2004; MATCZAK, 2009).

The form of allotment gardening practised thus far, is in a transition period. On the one hand, progress in the automotive industry favours the construction of "second homes" outside the city, on the other, the elderly and the less wealthy are interested in having allotments in the cities. These trends are quite clear at present, and it is likely that following the example of more developed countries, a part of the existing allotments will be liquidated for other purposes and social demand will be satisfied better by plots located outside the city. 
The typology, prepared by Duś (1992) based on the analysis of the development of allotment gardens gave no grounds for distinguishing the different types of recreational allotments, although the processes of change in the way allotments were designed and their increasing importance for recreational purposes were visible then. In a detailed study in Łódź, SzKuP (2013), distinguished four types of plot, of which $20.7 \%$ were recreational, $31.4 \%$ recreational and quasi-agricultural and $11.0 \%$ quasi-agricultural and recreational. Progressive changes in the usage of allotments are prerequisites for undertaking further studies of the recreational and health-improving functions of allotments as components of urban recreational space (SLAVU] BORCIC ET AL., 2014).

\section{Conclusion}

To sum up the considerations, it should be noted that in the process of historical development, the modern form of allotments has been created, which constitutes a characteristic element of the industrial landscape and an important element in the recreational use of cities in the Katowice conurbation. In this process, there has been a significant reduction in the leading economic function in favour of the benefits from their recreational function, which is evident in the ways the allotments are used. Leisure time spent in allotments serves a significant role for the residents of the Katowice conurbation and in terms of size, it may be comparable to other forms of recreation. A systematic increase in the importance of the recreational function is progressing with the simultaneous change and diversity of leisure activities in the gardens (http://bloodmountain.org/wp-content/uploads/ 2013/09/BMF_PR_2012.05.29.pdf).

A significant number of people at leisure and an increased level of investment in allotments and their equipment indicate the persisting recreational function of allotments (WAKEFIELD ET AL., 2007). All people, regardless of age or economic status, may take advantage of leisure time spent there. The use of allotments is most recommended for people who excessively exploit their mental and physical strength at work, and due to social and material status, it is of particular interest to retired people (AUSTIN ET AL., 2006; VAN DEN BERG ET AL., 2010). Because of their location close to their places of residence, recreation in gardens provides daily recuperation, at very little expense, and also for people with limited physical abilities.

\section{References}

Acton L. 2010. Allotment Garden: A Reflection of History, Heritage, Community and Self. (www.pia-journal.co.uk).

Andriotis K. 2006. Host, guests and politics, coastal resorts morphological change. Ann. of Tourism Research, 33, 4: 1079-1098.

Armstrong D. 2000. A survey of community garden in upstate New York: implications for health promotion and community development. Health and Place, 6, 4: 319-327.

Arnhold V. H. 1959-1960. Funktionswandel des Kleingartens Ein funktionales und soziales Problem. Berichte zur Deutschen Landeskunde, 24.

Austin E., Johnston Y., Morgan L. L. 2006. Community Gardening in a Senior Center: A Therapeutic Intervention to Improve the Health of Older Adults. Therapeutic Recreation J., 40, 1: 48-56.

Bellows A. 2004. One hundred years of allotment gardens in Poland. Food and Foodways: Explorations in the History and Culture of Human Nourishment, 12, 4: 247-276.

Berry B. 1980. Creating future geographies. Ann. of the Ass. of American Geogr., 70, 4.

Brown K., Jameton A. 2000. Public Health Implications of Urban Agriculture. J. of Public Health Policy, 21, 1: 20-39.

Butrymowicz B. 1971. Ludzie podeszłego wieku użytkownikami ogrodów działkowych. Zdrowie Psych., 1/2.

Chiusura A. 2004. The role of urban parks for sustainable city. Landsc. Urban Plan., 68: 129-138.

Coppock J. T. 1977. Second homes: Curie or blessing. Oxford Press, Oxford.

Crouch D., Ward C. 2007. The allotment: its landscape and culture. Five Leaves Publ., Nottingham.

Czarnecki W. 1968. Krajobraz i tereny zielone. [in:] Planowanie miast i osiedli. t. 3, PWN, Warszawa-Poznań.

Duś E. 1990. Ogrodnictwo działkowe w Górnośląskim Okręgu Przemysłowym. Geogr. Stud. et Dissert., 14: 93-117.

Duś E. 1992. Użytkowanie ogrodów działkowych w Górnośląskim Okręgu Przemysłowym. Geogr. Stud. et Dissert., 16: 135148.

Duś E. 1993. Tendencje zmian w rolniczym użytkowaniu ogrodów działkowych w świetle zagrożeń ekologicznych. [in:] Rolnictwo na obszarach wielofunkcyjnych. Mat. X Ogólnopol. sem. geogr.-roln., Kielce: 35-41.

Duś E. 1997. Przeszłość i współczesny stan ogrodnictwa działkowego w Chorzowie. Zesz. Chorzowskie, 1: 135-151.

Duś E. 2013. Allotment gardens and spatial development two case studies from the Katowice conurbation, Poland. Environ. \& Soc.-econ. Stud., 1, 4: 41-51.

Działkowiec 1970. Organ Krajowej Rady Pracowniczych Ogrodów Działkowych przy Centralnej Radzie Związków Zawodowych.

Działkowiec Śląski 1934-1939. Organ Związku Towarzystw Ogrodów Działkowych i Osiedli województwa śląskiego.

Familiengarten Und Andere Kleingartenbestrebungen In Ihrer Bedeutung Für Stadt Und Land. 1913: [in:] Bericht und Behandlungen der 6 Konferenz der Zentrale für Volks-Wohlfahrt in Danzig am 17 Juni 1912. Berlin.

Grahn P. 1985. Man's Needs for Urban Parks, Greenery and Recreation. Inst. For Landscape Planning, Swedish Agricultural Univ., Alnarp.

Hall C. M., Page S. 1999. The geography of tourism and recreation. Environment, place and space, Routledge, London - New York.

Izdebska A. 1979. Zdrowotność załóg górniczych a rekreacja. [in:] Żmuda S. (ed.) Rekreacja w aglomeracji katowickiej. Śl. Inst. Nauk., Katowice.

Kamiński A. 1971. Wychowanie do starości. Zdrowie Psych., 1-2. 
Kołomyjska G. 1982. Starzenie się społeczeństwa a funkcja rekreacji. [in:] Żmuda S. (ed.) Rekreacja $w$ aglomeracji katowickiej. Śl. Inst. Nauk., Katowice.

Kowalczyk A. 1993. Przyrodnicze uwarunkowania wypoczynku weekendowego mieszkańców Warszawy. [in:] Pietrzak M. (ed.) Ekologia krajobrazu w badaniach Terytorialnych Systemów Rekreacyjnych, Poznań.

Krauz K. 1979. Funkcja Leśnego Pasa Ochronnego Górnośląskiego Okręgu Przemysłowego w zakresie rekreacji. [in:] Żmuda S. (ed.) Rekreacja $w$ aglomeracji katowickiej. Śl. Inst. Nauk., Katowice.

Krzysztofik R. 2008. Aglomeracje miejskie. [in:] Tkocz M. (ed.) Województwo ślqaskie. Zarys geograficzno-ekonomiczny. WNoZ, Uniw. Śl., Sosnowiec: 22-25.

Kucharski W. 1988. Profilaktyka ekologiczna terenów przemysłowych $w$ aspekcie zmniejszenia narażenia człowieka. Wyd. Geol., Warszawa.

Lendholt W. 1975. Zieleń miejska i krajobraz. [in:] Buchwald K. \& Engelhardt W. (ed.) Ksztattowanie krajobrazu a ochrona przyrody. Wyd. PWRiL, Warszawa.

Lenihan J., Fletcher W. W. 1996. Health and the Environment. Glasgow-London, Blackie.

Liszewski S. 2009. Urban 'tourism exploration space': the example of Łódź. Tourism, 19, 1-2: 59-65.

Maier J. 1988. Towards the evaluation of natural and cultural potential of space for different forms of leisure activities. Palo Alto, Univ. Press.

Majdecki L. 2008. Historia ogrodów od XVIII wieku do współczesności. T. II. Wyd. Nauk. PWN, Warszawa.

Matczak A. 2009. The urbanization of summer holiday estates surroundinding Łódź: Wiśniowa Góra. Tourism, 19, 1-2.

Matczak A., Szkup R. 2010. Społeczna funkcja Rodzinnych Ogródków Działkowych (ROD). Przykład ROD w Łodzi. [in:] Sitek S. (ed.) „Stare i nowe” problemy badawcze w geografii społeczno-ekonomicznej. Sosnowiec: 177-195.

Mika M. 2004. Turystyka a przemiany środowiska przyrodniczego Beskidu Śląskiego. Inst. Geogr. i Gosp. Przestrzennej UJ, Kraków.

Moran D. M. 1990. The Allotment Movement in Britain, New York.

Orzeszek-Gajewska B. 1982. Kształtowanie terenów zieleni w miastach. PWN, Warszawa.
Pawlikowska-Piechotka A. 2009. Ogrody działkowe w rozwoju zrównoważonym współczesnego miasta. Probl. Ekol., 13, 2: 106-109.

Perez-Wazqueza., Anderson S., Rogers A. 2005. Assesing benefis from allotments as a komponent of urban agriculture in England. Earthscan and IDRC, London.

Piątkowska K. 1972. Ogrody działkowe - problem urbanistyczny. Biul. Inst. Urban. i Arch., 30: 133-141.

Polski Związek Działkowców. 2012. Stan Organizacyjny Okręgowego Zarządu Śląskiego Polskiego Związku Działkowców. Stan na dzień 1.I.2012 rok.

Przekrój. 1983. Tygodnik RSW Prasa-Książka-Ruch, nr 1974 z dn. 10.04.1983.

Riley P. 1979. The allotments campaign guide. Friends of the Earth, London.

Romanowski W., Eberhard A. 1972. Profilaktyczne znaczenie zwiększonej aktywności ruchowej człowieka. PZWL, Warszawa.

Saarinen T. F., Sell J. L. 1981. Environmental perception. Progress in Human Geogr., 5: 525-547.

Slavuj Borcic L., Lukic A., Cvitanovic M. 2014. Community Gardens in Zagreb, Croatia: Old/New Practices for the Local Sustainability. Book of Abstracts IGU Regional Conference, Kraków, Poland.

Szkup R. 2013. Użytkowanie rodzinnych ogrodów działkowych (ROD) przez społeczność wielkomiejską. Przykład Łodzi. Wyd. Uniw. Łódz., Łódź.

Tchórz A. 1977. Tereny zielone w konurbacji górnośląskiej. Stud. nad ekon. regionu, 9.

Tołwiński T. 1963. Urbanistyka. Zieleń w urbanistyce. PWN, Warszawa.

Toyne P. 1978. Recreation and environment. London, Macmillan.

Wakefield S., Yeudall F., Taron C., Reynolds J., Skinner A. 2007. Growing urban health: community gardening in south-east Toronto. Health Promot. Intern., 22, 2: 92-101.

Van Den Berg A., Van Winsum-Westra M., De Vries S., Van Dillen S. 2010. Allotment gardening and health: comparative survey anong allotment gardeners and their neighbors without an allotment. Environmental Health. (www.ehjournal.net/content/9/1/74).

http://bloodmountain.org/wp-content/uploads/2013/09/ BMF_PR_2012.05.29.pdf 